\title{
“...BECAUSE I’M JUST A STUPID WOMAN FROM AN NGO”: INTERVIEWS AND THE INTERPLAY BETWEEN CONSTRUCTIONS OF GENDER AND PROFESSIONAL IDENTITY
}

\author{
Marlene Miglbauer
}

\begin{abstract}
Over the last decade, using interviews to analyse identity construction has been gaining in popularity (de Fina 2003; Johnson 2006; Baynham 2011) and, given this interest, analysing identities has become a much debated issue that is being approached from various angles. Regarding interviews as interaction between the interviewee and interviewer, and stories in the interviews as emerging from interactional dynamics (de Fina 2009), this paper draws attention to the emergence of identity at different levels. First, identities emerge at the level of the interview narrative, which is ongoing talk as it evolves in real time and consists of reporting facts, giving opinions on, and explaining aspects of, various topics to the interviewer. Second, identities emerge in stories which are included in the ongoing talk. Stories refer to actions in the past, usually told in chronological order. In contrast to interview narratives which are initiated by the interviewer, stories in interviews are primarily instigated by the interviewees to further support their identity co-construction in the interview setting. The interview setting is thus the third level of identity construction in interviews.

By applying the framework of identities occurring at different levels in interviews and Positioning Theory (Harré and van Langenhove 1999), this paper analyses the construction of professional gender identities in the workplace, the interplay between these identities, and the dependence of these constructions on the 'interview as context'. The stories themselves reveal how, in the workplace, there may be a conflict between professional and gender identities. More specifically such stories make visible the way in which interviewees construct their professional identities in order to resist gender identities that are projected onto them.
\end{abstract}

Keywords: Identities; Gender; Interviews; Identity levels; Power; Positioning; Stories.

\section{Introduction}

Since 1975 when Lakoff's seminal work 'Language and Woman's Place' put gender on the linguistic research agenda, and following the dominance/deficit (Lakoff 1975) and the difference approaches (Tannen 1990) ${ }^{1}$, gender and language in the workplace has

\footnotetext{
${ }^{1}$ Whereas the dominance/deficit approach emphasised the fact that women speak a deficit language compared to the dominant language of men, the difference approach highlights the fact that due to
} 
been the subject of numerous studies (Edelsky 1981; West 1984; Woods 1989; Ainsworth-Vaughan 1992). After Butler's (1990) influential work in which gender was perceived to be a fluid and a performative social construct, and with the advent of the linguistic turn in the social sciences and humanities, discursive and social constructionist approaches began to develop and they began to be applied to data on gender and language in the workplace (e.g. Wodak 1997; McElhinny 1998; Holmes and Marra 2004). More recent work on gender in the workplace has also adopted the notion of gender(ed) discourses and identities (Baxter 2003; Holmes and Marra 2004; Holmes and Schnurr 2005; Mullany 2007).

As Holmes and Stubbe (2003: 11) point out: "Interaction and identity construction are dynamic interactional processes where meanings and intentions are jointly and progressively negotiated between the individuals involved in a given interaction". To take this further, negotiating meanings and intentions result in identities that emerge from discourse/s (Bucholtz 1999: 4). Even within disciplines, the term 'discourse' has a variety of meanings (see Mills 1997 for an overview). The theorisation of discourse suitable and relevant for this paper is Fairclough's (1992: 3) notion of discourses as "different ways of structuring areas of knowledge and social practice". Litosseliti and Sunderland (2002: 13) develop Fairclough's notion of discourse and claim that "discourse as social practice offers a way of seeing how we experience the world, in part through the representational capacity of language" (italics in original). Discourses are always related to other discourses, are part of a network or 'order' of discourse, and they support, contradict or compete with each other, thus they show a particular amount of intertextuality and interdiscursivity (see e.g. Coates 1997; Baxter 2003).

Gendered discourses (Sunderland 2004) position men and women differently as particular kinds of gendered behaviour are expected from them. However, women and men are not just constituted, rather they actively take up, negotiate or resist gendered subject positions, which means that they position themselves or can be positioned "as relatively powerful within one discourse but as relatively powerless within another, perhaps competing discourse" (Baxter 2003: 9). Therefore, power relations are also critical for identity constructions since they constantly shift and thus so do subject positions.

Litosseliti (2006: 62) points out that the construction of (gendered) identities is a two-way process, i.e. discourses constitute multiple identities and people's identities give rise to particular discourses. Litosseliti (2006: 62) refers to an example of such a construction, which could have been taken from my own data: A woman may be constructed as businesswoman, mother, feminist, and so on by her talk and how she is spoken about in a particular situation, and as discursive construction emerges in talk, recognisable discourses surrounding these subject positions are shaped, i.e. the possibilities and boundaries of discourses are negotiated or modified. For example, in some contexts and in order to counter the possible negative effects of being positioned as a working mother, a woman may attempt to position herself as a businesswoman and so downplay her identity as a mother in the workplace.

The fields of sociolinguistics (e.g. Baxter 2003; Mullany 2006; Angouri 2011), social sciences and business studies have all addressed the issue of the intersection

different upbringings for girls and boys, mixed-gender interaction should be regarded as cross-cultural communication. In both approaches, gender was taken for granted and was treated "as a demographic category that is given in advance" (Cameron 1996: 44). This resulted in a generalisation of "women talk like this and men talk like that'. 
between professional and gender identities. For example, Alvesson (1998) has studied gender in advertising companies, Jorgenson (2002) has investigated gender identities in the field of engineering, Linstead and Thomas (2002) have looked at managerial gender identities, and Tienari, Soderberg, Holgersson and Vaara (2005) have studied national and gender identities in the workplace. Moreover, some studies also specifically draw upon narratives for analysing identities in the workplace (Dyer and Keller-Cohen 2000; Mullany 2005; Holmes 2006a).

Narratives help speakers, both as individuals and as group members, make sense of the world - (Giddens 1991; Coates 2003; Johnstone 2001) and they are constructed and emerge in interaction (de Fina and Georgakopoulou 2008). A crucial function of narrating stories is to present and represent various kinds of identities (de Fina 2003: 5), which "emerge through the interplay between linguistic choices, rhetorical and performance strategies in the representation of particular story worlds, and the negotiation of such representations in the interactional world" (de Fina 2003: 24). This paper aligns with this research by analysing the constructions of gender and professional identities in the workplace. But instead of analysing these identity constructions in-situ, stories about workplace situations that are recounted in interviews with employees are drawn upon. This paper, therefore, analyses how gender and professional identities intersect and what kinds of professional and gender identities are constructed in the telling of the story in the interview context. As the story is embedded in the interview, these constructions both influence, and are influenced by, identity constructions during the interview itself. By applying the notion of different identity levels that are detectable in interviews, this paper shows the intersection of gender and professional identities as well as their interplay at different levels in the interview. Therefore, the following section deals with interviews as sites for identity constructions and a model of identity levels in interviews is introduced and outlined. After providing background information about the data and methodology, the analysis of the data applies Positioning Theory and the model of identity levels to specifically examine how the interviewees resist subject positions projected onto them in the workplace and how they construct powerful professional and gender identities both in the workplace and in the interview setting.

\section{Interviews as sites for identity constructions}

Interviews as a method of data collection have played a prominent role in the humanities and social sciences for a long time. However, the use of interviews within specific research methodologies has been hotly debated among scholars (Potter and Wetherell 1995; Goodwin 1997). Rapley (2001: 304) summarises this debate by suggesting that the core of this debate lies in the distinction between interviews as topic and interviews as resource. On the one hand, social sciences have traditionally considered interviews to be a resource which allows access to the "the interviewee's reality outside the interview". On the other hand, sociolinguists tend to use interviews as data/ topic and their focus is on the way in which "reality [is] jointly constructed by the interviewee and the interviewer" (Rapley 2001: 304).

One major argument put forward against using interviews in linguistic research is based on the distinction between 'natural' and 'unnatural' data. In contrast to conversations occurring in everyday life ('natural' data), interviews belong to the latter 
as the interview is staged and influenced by the interviewer. However, as early as 1964 , Cicourel referred to interviewing as a "specific form of social interaction" (Rapley 2001: 308 ; italics in original). Riessman (2008) argues that rules of everyday communication apply to interview settings; Mishler (1986) stresses the interviewer's active role in the interaction; and as Alvesson (2003:16) aptly puts it: "People talk with their bosses, they serve customers, they drive trucks. They also participate in interviews". Other researchers join in this argument by regarding the interview situation as "a socially and linguistically complex situation" (Alvesson 2003: 14) or by claiming that the "research interview is one (and only one) context for constructing the self [...and] does not merely reveal a social world [... but] also effects a social world" (Presser 2004: 83ff; italics in original).

During the interview, interviewees accomplish socially acceptable selfpresentations by reflecting on who they are and how they are defined by society and so identities become negotiable. In interviews, most identity work is done by the interviewee, and this is often achieved through stories (Johnson 2006; Wortham and Gadsden 2006; Baynham 2011). Interactional events are also represented because both the interviewer and the interviewee try to make sense of social reality by analysing social circumstances and roles (Holmes and Stubbe 2003). As the interviewer is an 'unknown' person, explicit discussions about the interviewee's identities are necessary (de Fina 2003: 26). This means that both local and global contexts are relevant and crucial. The former includes the interaction itself, i.e. the interview, whereas the latter addresses the "wider context of social and discursive practices and their dynamic connections with the discourse of specific actors" (de Fina 2003: 29).

Analysing workplace identities via interviews may appear complex but it is argued that it is possible to use the notion of identity levels to detect identity work in the workplace. Figure 1 illustrates the model of identity levels which appear in interviews.

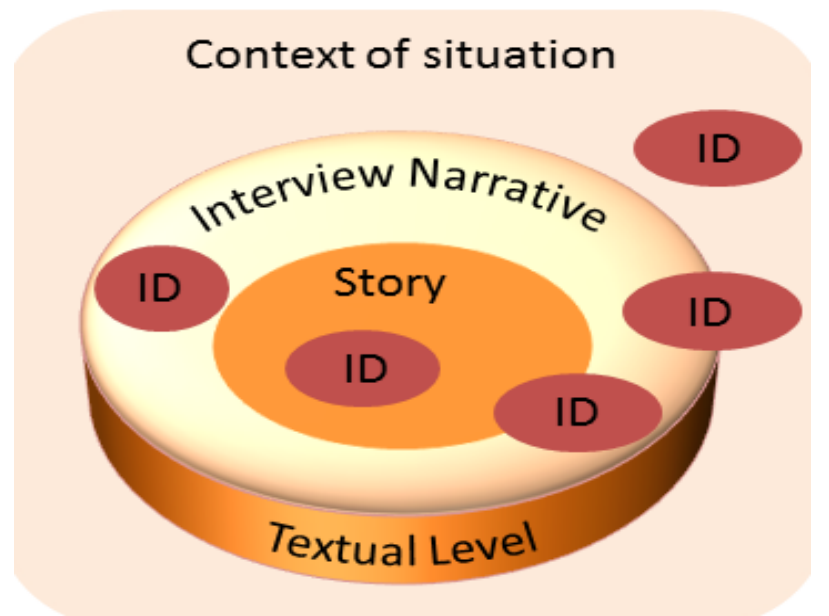

Figure 1: Model of three identity levels in interviews

As the figure shows, there are three levels at which identities are constructed and presented in the interviews. The first level is the non-textual level, which points to the context, the communicative situation, i.e. the interview. Following Firth's (1957: 36) approach of 'context of culture' and 'context of situation', in my interviews professional identity and identity as interviewee are part of the non-textual level. By asking the employees to be interviewed and explaining why they were chosen as interviewees, they are positioned as interviewees and employees/parents/experts, etc. by the interviewer as 
well as by themselves. Depending on the criteria of why particular people were chosen as interviewees, these so-called umbrella identities obviously differ from interview to interview.

During the interview various other identities are displayed at the textual level. These identities can be related to the 'contexts of experience' (Firth 1954) of the interlocutors or perceived as the "reporting context" (where the telling occurs) and the "reported context" (the context in which the original words were uttered [Tannen 1989]). I have called the reported context 'story' and the reporting context 'interview narrative'. As the terms story and narrative have been used interchangeably in research, a definition of how these terms are understood in this paper is vital. I consider interview narrative as ongoing talk as it evolves in real time and it consists of reporting facts, evaluating and explaining aspects to the interviewer, and giving opinions on various topics. The temporal aspect is the present. In contrast to the interview narrative, a story refers to actions in the past, which are usually chronologically ordered and "involve[s] the interplay of characters with interests, motives, emotions and moralities" (Watson 2009: 429). A story is included in the ongoing talk, i.e. interview narrative, and depending on the story, has more or less the structure of Labov's (1972) narrative model. These two frames, the interview narrative and the story have two different ways of instigating action. The interviewer instigates the former, whereas the interviewee often instigates the latter. The switch to telling a particular story is primarily selfinitiated by the interviewee.

The circles with the letters ID (abbreviation of identity) show examples of the location of identities in such an interaction. As I will show in the analysis, identities are constructed at each level, yet they also transcend the level boundaries, so reflexively influencing one another's construction of identity. In my data, gender and professional identities appear and are constructed in stories recounted in interviews. This means that identities are constructed at both textual levels (i.e., interview narrative and story). This is because even though gender and professional identities were constructed in the past when the story, which is told in the interview, took place, they are also constructed in the interview narrative during the interview. In particular, these stories have the function of supporting the identity construction during the interview when interviewees make evaluations or talk about themselves.

\section{Data and methodology}

The data for this paper are two extracts taken from two interviews: One with a female Croatian working in a multilingual workplace in Croatia and the other with a female Serbian employee working in a multilingual workplace in Serbia. As the command of English of both interviewees was very high, the interviews, which are part of a larger study on identity constructions of employees in Eastern Europe (Miglbauer 2010), were conducted in English.

The interviews are semi-structured interviews as they allow the respondents the time and scope to talk about their opinions on particular subjects. By using a list of items, which functions as a guideline of how to structure the interview and consists of the most important aspects and questions dealt with in the interview, it is possible to obtain comparable data (Schlehe 2003; Weller 1998). The interviews also resemble person-centred interviewing, in which the interviewee not only functions as informant 
but also as respondent. This allows the "interviewer [to] observe and study the interviewee as he or she behaves in the interview setting, as he or she reacts or responds to various probes, questions, and topics" (Levy and Hollan 1998: 335f). Consequently, it also allows the interviewer to make visible the way in which the interviewee negotiates and constructs various kinds of identities in the interview setting.

The interviews deal with various issues in the interviewees' workplaces such as work tasks, working hours, use of a foreign language in the workplace, and intercultural as well as gender issues. Interviewees mention discriminating tendencies in their workplaces based on gender and the two extracts analysed in this paper appear in this part of their interviews. The first interview extract is an example of an interview narrative interspersed with reported and direct speech as the interviewee is reporting a past conversation she had with her superior. Following Labov's narrative model, the second interview extract is an example of a story about a conversation between the interviewee and a member of the government.

The data has been approached by applying Positioning Theory (Harré and van Langenhove 1999; Bamberg 1997, 2004). This theory follows the poststructuralist tradition, which regards identity construction as a continuous process, which is accomplished through actions and words within and across different discourses and results in individuals being shaped by multiple subject positions. Positioning Theory approaches subject positioning and subject positions both by analysing the coconstruction of identity between speakers and their audiences and by analysing the connection between subject positioning and social power relations. In recent years, positioning theory has particularly been applied to narratives (Bamberg 2004; Georgakopoulou 2000; Lucius-Hoene and Deppermann 2004; Wortham and Gadsden 2006). This is because in narratives speakers construct identities or 'storied selves' (Sarbin 1986) and they also articulate descriptions and evaluations of themselves and others.

Bamberg (2004: 337) has adapted Positioning Theory specifically to storytelling and argues that positioning takes place at three different levels, which analyse "how characters within the story world are constructed in terms of, for example, protagonists and antagonists or as perpetrators and victims" (Positioning level 1), "how the speaker positions him/herself to the audience" (Positioning level 2) and "how speakers position themselves to themselves" (Positioning level 3). Harré and van Langenhove (1999: 24f) distinguish several distinct forms of intentional positioning, of which three are relevant for this paper. The first form is deliberate self-positioning, which occurs in every conversation where somebody wants to express his/her personal identity by either stressing his/her agency or by referring to his/her point of view or to events in his/her biography. Grammatically, this mode of self-positioning is done through the use of pronouns ('I') and by personal explanations of personal behaviour. The second form of positioning is forced self-positioning and this positioning occurs when the initiative does not lie with the person involved but with someone else. In order to classify people who are expected to function within institutions, this form of positioning may come from a person representing an institution or from people within institutions (such as superiors, clients, consultants and colleagues). As the analysis of the data will show, this form of positioning is highly relevant for the construction of professional and gender identities. Deliberate positioning of others is the third form of positioning and this can be done either when the person being positioned is present or absent. If the former is the case, the positioning can either be taken up or disregarded by the person positioned in 
the storyline of the speaker. However, by pointing out another individual's behaviour which is opposed, criticised, supported, etc. by the speaker, the speaker is also positioned. Van Langenhove and Harré (1999: 24) emphasise that these distinctions are merely analytic because several forms of positioning are likely to occur simultaneously in all conversations.

As well as applying Positioning Theory and detecting the discourses that the interviewees draw upon, I also analysed each first person singular and first person plural personal pronoun, and particularly its referent based on the content and positioning of the speaker (see van de Mieroop 2006 and Harding 2008 for an overview of different forms of the pronouns 'I' and 'we' and their analyses in an institutional setting). In my data twelve referents for both pronouns were found; examples of referents of these pronouns are 'I as interviewee', 'I as child', 'I as Croat', 'we as employees', 'we as women', 'we as company'. Professional and institutional identities are prevalent in the interviews, which is not surprising as the interviews deal with workplace issues. The analysis in the larger study where the interview extracts for this paper are taken shows that many identities are referred to, and constructed in, the interviews and quite often identities even shift within sentences (interpronoun and intrapronoun identity shifts; see Miglbauer 2010: 163ff for a detailed analysis). This supports Moore (1993: 204), who argues that multiple forms of difference intersect within individuals. Moore draws upon Anzaldúa's argument that gender and other aspects of identity are inextricably interconnected. She argues that individuals occupy multiple identity positions and thus have multiple voices with which to speak:

When we come into possession of a voice, we sometimes have to choose with which voice (the voice of the dyke, the Chicana, the professor, the master), in which voice (first person, third, vernacular, formal) or in which language (Black English, TexMex, Spanish, academese) to speak and write in (Anzaldúa 1990: xxiii; emphasis added)

Anzaldúa specifically connects identity positionings to language. Applied to the data, interviewees can choose to speak with the voice, for instance, of an employee, a mother, or a member of the postsocialist generation. They can do this by: Referring to themselves; using reported speech when recounting a story; applying a more formal register; or including more informal expressions in either English or their mother tongue.

\section{The interplay of gender and professional identities in interview narratives and stories}

The first example is taken from a Croatian female employee in her early 30s. Prior to the extract analysed below, the interviewee talks about having taken maternity leave after the birth of her child. Instead of a one-year maternity leave ${ }^{2}$, she took three months

\footnotetext{
${ }^{2}$ In 2007, when the interview was conducted, regulations in Croatia enabled women to take a year's maternity leave. Whereas the first six months are mandatory for the woman, the remaining six months can be split between the partners. The vast majority of Croatian women, however, take a year-long maternity leave (Nestić 2007).
} 
maternity leave. She emphasises that, because of work-related and financial issues, it was her decision to shorten her maternity leave. She points out that she does not regret her decision but feels that, because she went on maternity leave, she has been disadvantaged or even discriminated against in the workplace. In a story concerning a conversation she had with her superior, she provides an example of discriminating tendencies in the workplace.

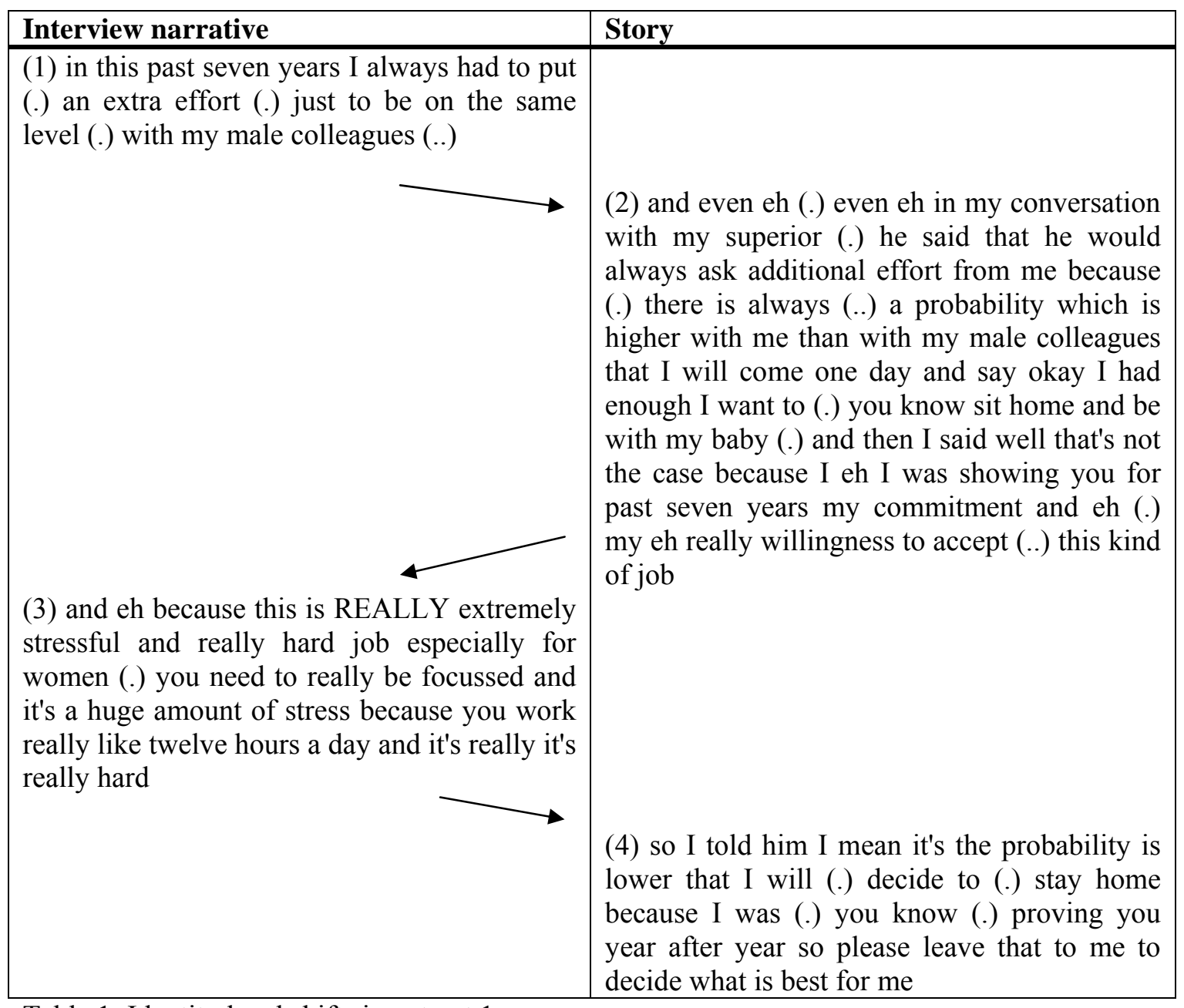

Table 1: Identity level shifts in extract 1

This extract is presented in table 1. The left-hand column shows the interview narrative, which consists of reporting facts, providing background information and evaluations, whereas the story itself is shown in the right-hand column. The table displays the switches between the textual identity levels. In this extract, there are three switches between the levels. The story is instigated by the interviewee (and thus not elicited by the interviewer) and this serves to support her statement and highlight her identity construction as a committed and self-confident employee.

In part one, on the interview narrative level, the interviewee positions herself as a committed and highly engaged employee. The explicit reference to time ('in these past seven years') underlines her positioning even further. Here in the interview she constructs professional identity, which also intersects with gender identity when gender becomes salient by referring to 'male colleagues'. This interplay of identities is 
strengthened by the interviewee's decision to support her statement by referring to a conversation she had with her superior.

This conversation is recounted in part two, which is on the story level. A switch from interview narrative to story occurs here in support of her statement and identity construction made in part one. The recounting of the conversation with her boss is verbalised by the use of direct and indirect reported speech. De Fina (2003: 105) suggests that a preference for direct reported speech may be a narrative evaluation strategy because "the animation of different voices in the story world contributes to a style of telling where a great deal of the evaluation of events is conveyed, not directly commented upon". This part shows alternating direct and indirect speech with the former slightly dominating. Even though the interviewee does not explicitly comment on, or evaluate, the conversation, by animating the words of her boss and herself, their emotional responses to the situation are detectable and conveyed. Her construction of professional identity is underlined. This is because the superior expects her to be, and positions her as, a highly committed employee. When she mentions the discriminating aspect in the story, gender becomes salient again. By giving the reason for his expectations of his female subordinates, he positions her not only as a woman but also as a mother who may jeopardise her position as employee by prioritising her identity as mother. Thus she is positioned as an unreliable subordinate and as 'other' compared to the male subordinates. It is obvious in this conversation that her superior primarily positions her as a working mother who might decide to take maternity leave. The interviewee rejects this positioning and highlights her professional identity by referring to her commitment to, and engagement with, the organisation. She is putting the professional identity of a committed female employee over her gender identity as a working mother. Interestingly, this phenomenon has also been shown on a broader level in Ukrainian business settings where the business identity predominates over women's identity (Zhurzhenko 2001: 42).

Both the boss and the employee draw upon and support the 'work more to be equal' - discourse ${ }^{3}$. The interviewee does so in the interview narrative (part one) and her superior in the story (part two). Studies by Coates $(1996,2003)$ indicate that within narratives (stories), social and cultural boundaries of acceptable behaviour are reflected upon and so stories are also used to voice criticism of cultural expectations. This is what the function of this story entails: The interviewee reflects upon socially acceptable behaviour and criticises the social boundary of behaviour through her behaviour in the story. This sequence shows that the boss is also drawing on another discourse, which is the 'women are the primary carers of children' - discourse. In the boss's opinion, professional and gender identities clash in the workplace, resulting in him fearing that female employees may leave the staff by taking maternity leave. These two discourses are detectable in several interviews in the larger study. Whereas the former is never

\footnotetext{
${ }^{3}$ Historically speaking, in South-Eastern Europe, this discourse is relatively new and it only gained substance after the transition to capitalism and the abolition of gender equality in 1991. Both male and female interviewees stress that their jobs are highly competitive and performance-driven, which, taking the history of South-Eastern Europe into consideration, is quite new. In the post-communist era and with the increasingly competitive nature of the workplace, the fact that female employees need to work harder to gain equality is simply accepted. This discourse is related to the discourse of 'individualisation', which means that everybody is responsible for advancing their own career, and thus it is the women's fault if they do not advance in their career because they can, and indeed should, 'prove themselves'. According to the interviewees, both discourses were unknown in their parents' generation.
} 
contested but accepted and consequently reified, the latter is indeed resisted (see Miglbauer [2010: $80 \mathrm{ff}$ ] for a more detailed discussion on these two discourses).

The interviewee interrupts her storytelling and switches to the interview narrative level (part three) for two reasons: First, this underlines her construction of a committed female employee; and second, this provides background information on 'this kind of job' for her audience, i.e. the interviewer, who is an academic and thus an outsider. As well as constructing her professional identity, the discourse identity (Zimmerman 1998) of interviewee intersects here. She positions herself as an interviewee who gives information on the kind of job and thus positions the interviewer as someone who lacks this knowledge. Most interestingly, this switch to the interview narrative level is also indicated by the change from the first person pronoun singular to the generic you. The generic you is used to show general experience or a fact from the speaker's point of view. It also underlines the dramatic aspect of the talk (Holmes 1998), and it also distances the speaker from the situation. To take this further, as well as distancing herself from the situation, the interviewee also 'distances' herself from the past events recounted in the story. This part is primarily instigated by the presence of the interviewer to whom the interviewee explains and evaluates the nature of such jobs. According to Labov's (1972) model of narratives, part three of this extract belongs to the evaluation clause of a story. However, depending on the interviewee's interlocutor, evaluation clauses may be different and, indeed, they may even be omitted. Therefore, I argue that when analysing identities in stories embedded in conversation, evaluation clauses belong to the interview narrative level rather than to the story level.

In part four, narrating the story is continued and the interviewee constructs another aspect of her professional identity, namely that of a self-confident employee. She repeats the temporal aspect of her commitment and stresses that her gender identity will not be a 'threat' to her professional identity. She positions herself both as a very selfconfident person/ interviewee and as a professional working mother, who is demanding agency regarding her life and the decisions she needs to make. The very last sentence is interesting in so far as she positions herself as powerful by resisting her boss's position despite the fact that he is her hierarchic superior.

There are two kinds of intersections in this example: First, the intersection of professional, gender and interviewee identities, which reflexively support each other. Second, the intersection between identities constructed in the interview and in the story. Whereas on the one hand the identities in the story could stand on their own and disclose what and how the interviewee constructed her identities in the workplace, on the other hand the identities at the interview level are enriched by the identity construction in the workplace.

The next example is taken from a Serbian female employee in her early 30 s. Prior to the extract provided and analysed below, the interviewer asks her whether there are any aspects of her work that she does not totally approve of. She mentions insecurity as she has been given a temporary contract and she immediately starts pointing out the difficulty of being a woman working in the field of mine clearance as part of her work for an NGO. She also addresses the issue of the negative perception of NGOs in Serbia. She mentions that as a female NGO employee she has been confronted with difficult situations. It is here, in the conversation with the deputy minister she was interviewing, that she starts talking about such a situation, in which she positions herself as a selfconfident expert and caring person. 
As in extract 1 , the story is also instigated by the interviewee. This supports her argument and highlights the identity construction as a committed and expert employee at the interview narrative level.

In part one of the interview narrative, the interviewee presents interviewee, gender, and professional identity. Gender 'tags along' because of what she was talking about right before this extract. The interviewee constructs all three intersecting identities as being powerless due to people's perceptions of women working in the field of explosives. The adjective 'funny' used to describe situations in the past may be perceived as ambiguous - it may be interpreted as situations to laugh about, but it could also be understood as situations which were difficult to handle.

The interviewee provides an example of such a 'funny situation' and switches to the story level in part two. She positions herself as an NGO employee rather than as a woman. As the deputy minister would not talk to her, aspects of hierarchy, authority and power relations are made visible. At this point, the interviewee reveals the perceptions people have about NGOs in Serbia ${ }^{4}$. During this part, the interviewee presents the deputy minister's words in direct speech to reveal how she - as an NGO employee - is positioned by others. In this extract, the deputy minister does not position her as a woman in the first place but refers to, and highlights, her professional identity.

The interviewee starts by trying to overcome the failure to get the interview she wanted to conduct with the deputy minister. She constructs her professional identity as a committed and forthright NGO employee, who, by demanding some decisive information she needs for her work, is not giving in to the deputy minister's negative attitude towards her. Before she utters her straightforward demand ('I want you to tell me'), she emphasises their mutual interest in discovering what exactly happened in 1999. The strict nature of a purely workplace meeting is transcended as she does not address him as deputy minister but as a private person who had to deal with the effects of explosives on the inhabitants of the town in question. Her strategy of not strictly adhering to the rules for this work meeting by drawing upon the deputy minister's identity as private person also shows the 'tactical nature' of constructing various aspects of identities. Calling upon him as a private person rather than as the deputy minister surprises him. She explains his reaction to her 'violation' of a work meeting in part three by emphasising how she is positioned by other people and by the deputy minister. She articulates their opinion about employees and more specifically about female employees at NGOs. As in extract 1, this evaluation clause (Labov 1972) is provided due to the presence of the interviewer. Whereas the deputy minister overtly highlights her professional identity, it is here that gender tags along - introduced by the interviewee as she brings it to the surface. This positioning as 'stupid woman' is contrasted by and contradicts her own positioning as an expert and shows that despite being in a relatively powerless position (as the one asking to be listened to), she can become more powerful by being an expert, which is an identity she continues constructing in part four.

\footnotetext{
${ }^{4}$ During the Milošević era, NGOs were successfully stifled by state-controlled media because they were perceived a threat to the regime. It was, thus, claimed that their work was directed against the interests of the nation since they were in favour of foreign economic and political domination (Grødeland 2006).
} 


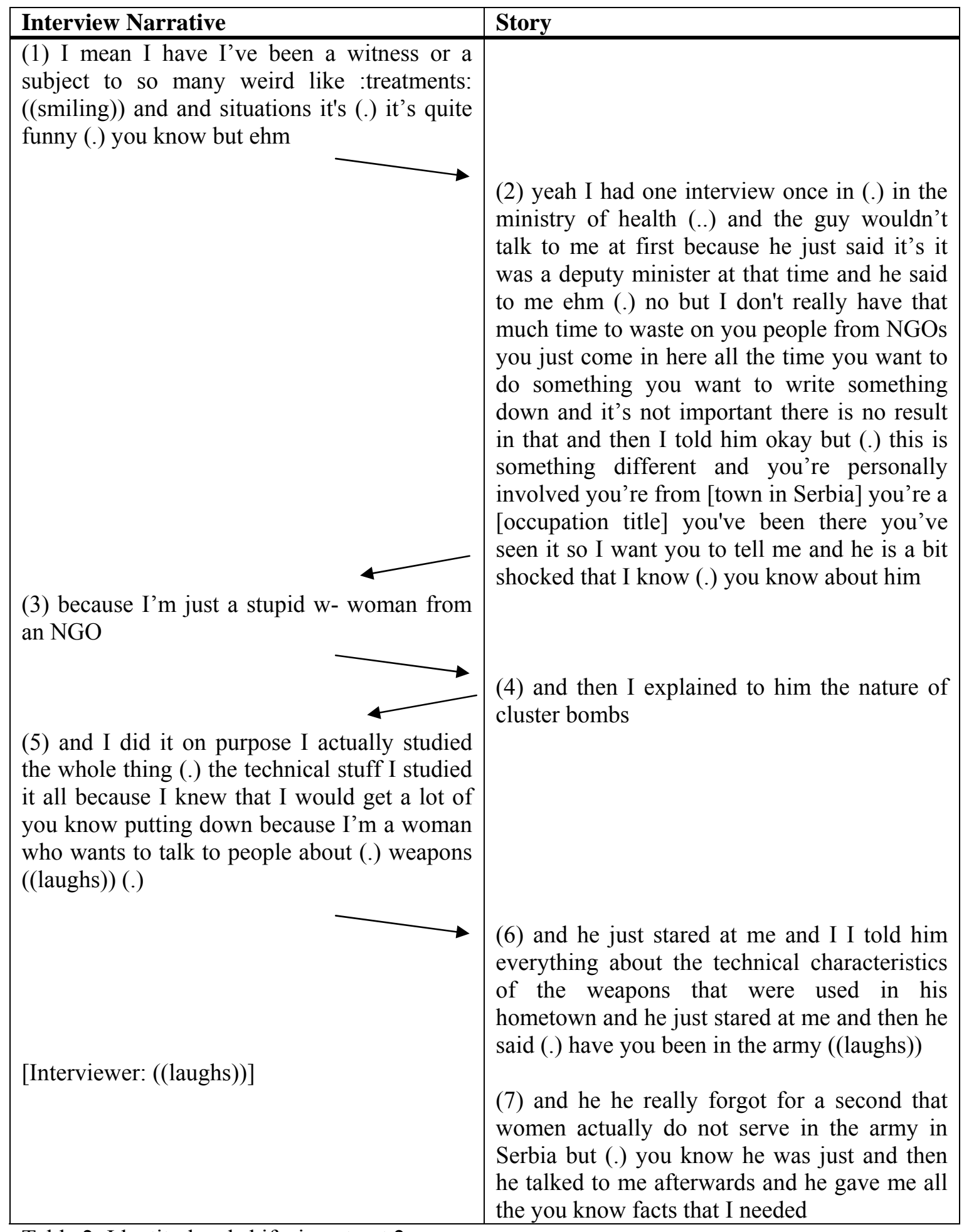

Table 2: Identity level shifts in extract 2

In part four, the story is briefly continued and the interviewee constructs a professional identity as an expert on cluster munitions before switching back to the interview narrative level which occurs in part five. The switch to part five, which is theoretically an interruption of the story, is used to provide background information and a reason for the interviewee's behaviour. By explaining why she became an expert, the interviewee constructs a committed professional and gender identity. She had to become 
an expert because, on account of her gender, she knew she would be positioned as a non-expert. As in part three, she repeats the reason both for the behaviour of others and her own reaction which is due to her gender vis-à-vis her professional interest in munitions. Her laughter indicates knowledge that her self-positioning 'violates' the dominant discourse of 'weapons are men's toys'. The deputy minister's body language in reaction to her expertise also underlines this violation as does his verbal reaction when he asks if she has been in the army. But in asking this question, it is revealed that he has indeed positioned her as a woman during their conversation, but it is only here that it becomes obvious. Her laughter reveals the humorous aspect of the situation. The interviewer joins in with the laughter and both the interviewee and the interviewer display knowledge about the fact that in Serbia women do not serve in the army. Both of them are also aware of the fact that, by catching the deputy minister off guard and by overcoming the initial objections to doing the interview, the interviewee's forced selfpositioning as expert has been successful. After the shared laughter, in part seven she again not only constructs her professional identity as an expert on cluster munitions but she also constructs a fairly powerful gender identity. This is because she has obtained the information she wanted from the deputy minister.

By analysing the various positionings, this interview extract shows different mechanisms that are at play in an interview narrative that includes a story. The interviewee constructs herself as a self-confident, knowledgeable, female employee who not only opposes the discourse 'weapons are men's toys' but she also manages to succeed in constructing herself as an expert. Gender and professional identities thus intersect and shift in relative importance as the talk progresses. Moreover, by switching between levels, the intersection of identities at story and narrative level mutually reinforce each other.

\section{Conclusion}

The analysis of both extracts shows that "individuals engage in multiple identity practices simultaneously, and they are able to move from one identity to another" (Bucholtz 1999: 209). Stories about past events enable researchers to analyse past identity constructions. However, what is equally important for identity construction is the story's embeddedness in the interaction because speakers "generally attune their stories to various local, interpersonal purposes, sequentially orienting them to prior and upcoming talk" (de Fina and Georgakopoulou 2008: 382). De Fina and Georgakopoulou continue to point out that "any representations of self" need to be placed in the "context of this type of relational and essentially discursive activity". This embeddedness of stories in the interview narrative is essential to reveal the purpose of the story and to support identity construction at both the story and the interview narrative level. The analysis shows that both levels are interdependent, as are the identity constructions. In contrast to valuable studies which use and analyse data gained from the workplace (e.g. Holmes 2006b), analysing and drawing upon recountings of workplace situations, therefore, make visible three important phenomena. Firstly, as well as revealing what happened in the event, the interviewees also provide evaluations of the situation as the story is interwoven in the interview narrative. Secondly, the story has the function of emphasising and supporting identity construction during the interview setting. Finally, 
the examples show that, in order to underline their identity constructions, the interviewees switch seamlessly between textual identity levels.

The two examples analysed in this paper show that the role of the stories is to clarify the statements made by the interviewees right before the beginning of the story. In the first extract, in order to construct herself as a sacrificing female employee at the interview narrative level, the interviewee feels the need to justify past behaviour. However, at the story level, another aspect of her professional identity is constructed that of a self-confident employee. This construction intersects with gender identity, which is not introduced by herself but by someone else (in this case her superior). Gender is made salient in a situation where it should not be, or is not, appropriate.

In contrast to extract 1 , in extract 2 gender is salient right from the beginning as the interviewee introduces it at the interview level right before the switch to the story level. Within the story, professional identity as an expert and a forthright NGO employee is constructed. Gender is not made salient explicitly but, on account of the interview narrative where gender identity is prominent, it tags along. In the interview narrative, the interviewee constructs herself first as a victimised female employee and then she constructs herself as a female expert. This expert identity is also carried over to the story level where the professional identity of a self-confident employee is constructed. So, not only do identities intersect, but identity constructions also transcend identity levels.

These projected gender identities or deliberate positioning of others (Harré and van Langenhove 1999) and the 'others' drawing upon various discourses, triggers forced self-positioning by highlighting their professional identities. Both women apply this positioning successfully, which is also shown by the shift in power relations; from being powerless to being powerful. Both examples consist of recounted face-to-face encounters in the workplace where the participants are unequal, and power is exercised by the participant higher in rank. However, by constructing and emphasising their (powerful) professional identities, the women, who are hierarchically subordinate to their interlocutors, contest the power imbalances in the situation. This power can be perceived as 'power in discourse' (Fairclough 2001: 36), which is concerned with "how orders of discourse, as dimensions of the social orders of social institutions or societies, are themselves shaped and constituted by relations of power". In the first example, the interviewee clearly demands agency for her life and her professional career, and in the second example, the interviewee succeeds in being taken seriously. This shift occurs due to the need to negotiate identities, voluntarily or not, because, from the interviewee's point of view, gender was not relevant in the workplace situations. By constructing powerful professional identities, both women challenge the projection of, and the reference to, their gender identities. Both women position themselves as experts, and as valuable and highly-committed employees, and thus they succeed in highlighting their professional identities in these workplace situations.

The analysis also shows the impact of particular kinds of gendered behaviour that is differentially expected from men and women. Both employees found themselves in a situation where they could either resist or acquiesce to what was expected of them in these specific workplace situations. However, they resisted the discourses that were at play and by doing so constructed varied and persuasive professional identities.

Approaching interview data with the model of two different identity levels enables us both to detect the intersection between identity constructions made at different points in time and it also allows us to demonstrate the interdependence of these identity constructions at both levels of analysis. In both extracts, professional identities and 
gender identities not only shift between the two genres (interview narrative and story) but their constructions are also reflexively linked so as to reinforce each other.

\section{Appendix}

\section{Transcription Conventions:}

(.) indicates a pause of one second or less

(..) indicates a pause of two seconds or more

((laughs)) additional information

[word] indicates original word was made anonymous

:word: ((laughs)) indicates speaking and laughing simultaneously

WORD capital letters indicate emphasis

wor-dash indicates word was cut off by speaker; eh/ehmfillers

\section{References}

Ainsworth-Vaughan, N. (1992) Topic transitions in physician-patient interviews: Power, gender and discourse change. Language in Society 21: 409-426.

Alvesson, M. (1998) Gender relations and identity at work: A case study of masculinities and femininities in an advertising agency. Human Relations 51.8: 969-1005.

Alvesson, M. (2003) Beyond neopositivists, romantics, and localists: A reflexive approach to interviews in organizational research. Academy of Management Review 28.1: 13-33.

Angouri, J. (2011) 'We are a masculine profession...': Constructing gender identities in a consortium of two multinational engineering companies. Gender and Language 5.2: 373-403.

Anzaldúa, G. (ed.) (1990) Borderlands/ La Frontera: The new mestiza. San Francisco: Spinsters/ Aunt Lute.

Bamberg, M. (1997) Critical personalism, language and development. Theory \& Psychology 10.6: 749767.

Bamberg, M. (2004) 'I know it may sound mean to say this, but we couldn't really care less about her anyway': Form and functions of "Slut Bashing" in male identity constructions in 15-year-olds. Human Development 47: 331-353.

Baxter, J. (2003) Positioning Gender in Discourse: A Feminist Methodology. Basingstoke: Palgrave.

Baynham, M. (2011) Stance, positioning, and alignment in narratives of professional experience. Language in Society 40: 63-74. 


\section{Marlene Miglbauer}

Bucholtz, M. (1999) Bad examples: Transgression and progress in language and gender studies. In M. Bucholtz, A.C. Liang, and L.A. Sutton (eds.), Reinventing Identities: The Gendered Self in Discourse. Oxford: Oxford University Press, pp. 3-24.

Butler, J. (1990) Gender Trouble: Feminism and the Subversion of Identity. New York: Routledge.

Cameron, D. (1996) The Language-gender interface: Challenging co-optation. In V. Bergvall, J. Bing, and A. Freed (eds.), Rethinking Language and Gender Research: Theory and Practice. London: Longman, pp. 31-53.

Coates, J. (1996) Women talk. Oxford: Blackwell.

Coates, J. (1997) Competing discourses of femininity. In H. Kotthoff, and R. Wodak (eds.), Communicating Gender in Context. Amsterdam: John Benjamins Publishing Company, pp. 285-313.

Coates, J. (2003) Men talk. Oxford: Blackwell.

De Fina, A. (2003) Identity in Narrative: A Study of Immigrant Discourse. Amsterdam/ Philadelphia: John Benjamins Publishing Company.

De Fina, A. (2009) Narratives in interview - The case of accounts: For an interactional approach to narrative genres. Narrative Inquiry 19.2: 233-258.

De Fina, A., and A. Georgakopoulou (2008) Analysing narratives as practices. Qualitative Research 8: 379-387.

Dyer, J., and D. Keller-Cohen (2000) The discursive construction of professional self through narratives of personal experience. Discourse Studies 2.3: 283-304.

Edelsky, C. (1981) Who's got the floor? Language in Society 10: 383 - 421.

Fairclough, N. (1992) Discourse and Social Change. London: Polity.

Fairclough, N. (2001) Language and Power. 2nd ed. Harlow: Pearson.

Firth, J.R. (1957) Papers in Linguistics. 1930-1951. London: Oxford University Press.

Giddens, A. (1991) Modernity and self-identity.Self and society in the late modern age. Cornwall: Polity Press.

Georgakopoulou, A. (2000) Analytical positioning vis-à-vis narrative positioning. Narrative Inquiry 10.1: $185-190$

Goodwin, M.H. (1997) Towards families of stories in context. Journal of Narrative and Life History 7.14: $107-112$.

Grødeland, Å.B. (2006) Public perceptions of non-governmental organisations in Serbia, Bosnia \& Herzegovina, and Macedonia. Communist and Post-Communist Studies 39: 221-246.

Harding, N. (2008) The 'I', the 'me' and the 'you know': Identifying identities in organisations, Qualitative Research in Organizations and Management: An International Journal 3.1: 42-58.

Holmes, J. (1998) Generic pronouns in the Wellington Corpus of Spoken New Zealand English, Kotare 1.1, http://www.nzetc.org/tm/scholarly/tei-Whi011Kota-t1-g1-t5.html.

Holmes, J. (2006a) Workplace narratives, professional identity and relational practice. In A. de Fina, D. Schiffrin, and M. Bamberg (eds.), Discourse and Identity. Cambridge: Cambridge University Press, pp. 166-187. 
Holmes, J. (2006b) Gendered Talk at Work. Constructing Social Identity through Workplace Interaction. Malden, Mass: Blackwell.

Holmes, J., and M. Stubbe (2003) Power and Politeness in the Workplace: A Sociolinguistic Analysis of Talk at Work. Harlow: Longman.

Holmes, J., and M. Marra (2004) Relational practice in the workplace: Women's talk or gendered discourse? Language in Society 33: 377-398.

Holmes, J., and S. Schnurr (2005) Politeness, humour and gender in the workplace: Negotiating norms and identifying contestation. Journal of Politeness Research: Language, Behaviour, Culture 1.1: 121149 .

Johnson, G.C. (2006) The discursive construction of teacher identities in a research interview. In A. de Fina, D. Schiffrin, and M. Bamberg (eds.), Discourse and Identity. Cambridge: Cambridge University Press, pp. 213-232.

Johnstone, B. (2001) Narrative. In D. Schiffrin, D. Tannen, and H.E. Hamilton (eds.), The Handbook of Discourse Analysis. Oxford: Blackwell, pp. 635-649.

Johnson, G.C. (2006) The discursive construction of teacher identities in a research interview. In A. de Fina, D. Schiffrin, and M. Bamberg (eds.), Discourse and Identity. Cambridge: Cambridge University Press, pp. 213-232.

Jorgenson, J. (2002) Engineering selves: Negotiating gender and identity in technical work. Management Communication Quarterly 15.3: 350-380.

Lakoff, R. (1975) Language and Woman’s Place. New York: Harper and Row.

Labov, W. (1972) Language in the Inner City. Philadelphia: University of Pennsylvania Press.

Levy, R., and D. Hollan (1998) Person-centered interviewing and observation. In H.R. Bernard (ed.), Handbook of Methods in Cultural Anthropology. Walnut Creek, Calif: Altamira Press, pp. 333-364.

Linstead, A., and R. Thomas (2002) 'What do you want from me?': A poststructuralist feminist reading of middle managers' identities. Culture and Organization 8.1: 1-20.

Litosseliti, L., and J. Sunderland (eds.) (2002) Gender Identity and Discourse Analysis. Amsterdam: John Benjamins Publishing Company.

Litosseliti, L. (2006) Gender \& Language. Theory and Practice. London: Hodder Arnold.

Lucius-Hoene, G., and A. Deppermann (2004) Narrative Identität und Positionierung (Narrative identityandpositioning). Gesprächsforschung - Online-Zeitschrift zur verbalen Interaktion 5: 166-183.

McElhinny, B. (1998) 'I don't smile much anymore': Affect, gender and the discourse of Pittsburgh police officers. In J. Coates (ed.), Language and Gender. A Reader. Oxford: Blackwell, pp. 309-327.

Miglbauer, M. (2010) Postsocialist globalised workplaces in Croatia and Serbia: Work characteristics, gender and identities. Unpublished Ph.D. thesis, University of Vienna.

Mills, S. (1997) Discourse. London: Routledge.

Mishler, E.G. (1986) Research interviewing: Context and narrative. Cambridge, MA: Harvard University Press. 


\section{Marlene Miglbauer}

Moore, H. (1993) The differences within and the differences between. In T. des Valle (ed.), Gendered anthropology. London/ New York: Routledge, pp. 193-204.

Mullany, L. (2006) Narrative constructions of gender and professional identities. In T. Omoniyi, and G. White (eds.), The Sociolinguistics of Identity. London: Continuum, pp. 157-172.

Mullany, L. (2007) Gendered Discourse in the Professional Workplace. Basingstoke: Palgrave.

Nestić, D. (2007) Differing characteristics or differing rewards: What is behind the gender wage gap in Croatia? EIZ Working Papers 0704, http://hrcak.srce.hr/file/106596.

Potter, J., and M. Wetherell (1995) Natural order: Why social psychologists should study (a constructed version) of natural language, and why they have not done so. Journal of Language and Social Psychology 14.1-2: 216-222.

Rapley, T.J. (2001) The art(fulness) of open-ended interviewing: Some considerations on analysing interviews. Qualitative Research 1.3: 303-323.

Riessman, C.K. (2008) Narrative methods for the human sciences. Thousand Oaks: Sage.

Sarbin, T.R. (ed.) (1986) Narrative Psychology. The storied nature of human conduct. New York: Praeger.

Schlehe, J. (2003) Formen qualitativer ethnographischer Interviews (Types of qualitative ethnographicinterviews). In B. Beer (ed.), Methoden und Techniken der Feldforschung. Reimer: Berlin, pp. 71-93.

Tannen, D. (1989) Talking voices. Cambridge: Cambridge University Press.

Tienari, J., A. Soderberg, C. Holgersson, and E. Vaara (2005) Gender and national identity constructions in the cross-border merger context. Gender, Work and Organization 12.3: 217-241.

Van de Mieroop, D. (2006) Identity construction in institutional speeches: The crucial role of pronouns. Lodz Papers in Pragmatics 2: 81-103.

Van de Mieroop, D. (2009) A rehearsed self in repeated narratives?: The case of two interviews with a former hooligan. Discourse Studies 11.6: 1-20.

Van Langenhove, L., and R. Harré (1999) Introducing positioning theory. In R. Harré, and L. van Langenhove (eds.), Positioning Theory: Moral contexts of Intentional Action. Oxford: Blackwell, pp. 1431 .

Watson, T.J. (2009) Narrative, life story and manager identity: A case study in autobiographical identity work. Human Relations 62.3: 425-452.

Weller, S.C. (1998) Structured interviewing and questionnaire construction. In H.R. Bernard (ed.), Handbook of Methods in Cultural Anthropology. Walnut Creek, Calif: Altamira Press, pp. 365-409.

West, C. (1984) When the doctor is a lady. Symbolic Interaction 7: 87-106.

Wodak, R. (1997) 'I know we won't revolutionize the world with it, but ...': Styles of female leadership in institutions. In H. Kotthoff, and R. Wodak (eds.), Communicating Gender in Context. Amsterdam: John Benjamins Publishing Company, pp. 335-370.

Woods, N. (1989) Talking shop: Sex and status as determinants of floor apportionment in a work setting. In J. Coates, and D. Cameron (eds.) Women in their Speech Communities: New Perspectives on Language and Sex. London: Longman, pp. 141-157. 
Wortham, S., and V. Gadsden (2006) Urban fathers positioning themselves through narrative: An approach to narrative self-construction. In A. de Fina, D. Schiffrin and M. Bamberg (eds.), Discourse and Identity. Cambridge: Cambridge University Press, pp. 314-341.

Zhurzhenko, T. (2001) Free market ideology and new women's identities in postsocialist Ukraine. The European Journal of Women's Studies 8.1: 29-49.

Zimmerman, D. (1998) Identity, context and interaction. In C. Antaki, and S. Widdicombe (eds.), Identities in Talk. London: Sage, pp. 87-106.

MARLENE MIGLBAUER has a Ph.D. in Social and Cultural Anthropology (with a focus on linguistics) from the University of Vienna and works as a lecturer at the Department of English at the University of Applied Sciences Wiener Neustadt in Austria. Her research focuses on identity constructions in narratives and institutional settings, language use in multilingual workplaces, and gender in postsocialism.

Address: University of Applied Sciences Wiener Neustadt, Department of English, Johannes-GutenbergStraße 3, A-2700 Wiener Neustadt.

E-mail: marlene.miglbauer@fhwn.ac.at 